文章编号：1673-9493 (2017) 02-0010-08 中图分类号：TU984 文献标识码：A DOI : 10.22217/upi.2016.565

\title{
美国新城新区发展回顾与借鉴
}

\section{A Review on Planned Cities and Communities in the USA}

赵星炼 杨滔

Zhao Xingshuo, Yang Tao

摘要: 本文从回顾工业化后期以来美国新城 新区发展历程入手, 整理和分析美国各阶段新 城新区发展背景、动因、特征、措施等, 归纳 一般特征和规律, 特别强调了市场的积极作 用，以期对我国新城新区发展提供借鉴。

Abstract: This article starts with historical transformation of the planned cities and towns in the USA since the late industrialization, and then makes analysis on the background, mechanism, features and technical tools of building those planned cities and towns. Based on which, some general features and patterns, focusing on the positive effects of market, have been founded, and this could cast light on the new cities and towns planned and built in China.

关键词: 美国; 新城新区;市场; 区位;专业化; 新城市主义

Keywords: The USA; Planned Cities and Towns; Market; Location; Professionalism; New Urbanism

作者: 赵星炼, 住房和城乡建设部城乡规划管理 中心副研究员

杨滔, 清华大学建筑学院《城市设计》副 主编
引言

从两千多年前柏拉图《理想国》中的完美城邦, 到工业革命时期出现了企 业城市, 到近代霍华德（Ebenezer Howard）的“田园城市”（garden city）, 到美 国的汽车小镇和科技园区, 再到我国各类新城新区如火如茶的建设, 都反映了人 们对理想生活居所的不解追求。正如田园城市的倡导者查尔斯 - 本杰明 - 珀德姆 (Charles Benjamin Purdom) 所言 : 新城的建设就是形成便捷、健康、美丽的生 活和工作场所 ${ }^{[1]}$ 。而从学术理论上, 世界各地的新城新区都在探索一个问题 : 新 的理想聚居地能否以及如何一次性地有序建设好?

我国的新城新区建设始于 20 世纪 80 年代, 多为各级政府及其有关部门设立, 并给予一定优惠政策扶持发展，从而形成在空间上具有一定独立性的区域 ${ }^{[2]}$ 。这 些新城新区对于促进经济发展、引进投资、技术创新、产业升级、城市建设等方 面发挥了重要作用。但近年来, 一些地方也暴露出盲目设立、用地粗放、恶性竞争、 效益低下等问题 ${ }^{[3,4]}$ 。

相比欧洲与亚洲不少国家都采取政府主导发展新城新区的模式，在崇尚市场 经济效率的美国，情况则有所不同。总的来讲，市场在新城新区建设发展中发 挥了更多的作用; 相比为数不多的几次政府主导的新城运动, 市场主导的新城 新区发展更为成功。此外, 美国孕育和发展的“新城市主义”(New Urbanism), 也影响到 21 世纪美国对新城新区的建设, 同时广泛引发了对城市发展模式的 重新思考。

在美国，与我国新城新区对应的概念为“规划建设的社区” (Planned community) 或 “规划建设的城市” (Planned City)。一般而言, 是指在原来未 开发利用的地方, 从一开始就经过精心规划设计而建设的社区或者城市。作为

“新大陆”, 美国有不少城市从殖民地时期起就在未开发地上经过规划而建设, 例如费城 (Philadelphia)、美国的首都华盛顿哥伦比亚特区 (Washington, D.C.) 以及不少州府城市。在它们建设之初, 也应视为新城新区。然而考虑到现代 意义的城市规划是从 20 世纪早期才得以建立, 本文从回顾工业化后期以来美 国新城新区的发展历程人手（表 1) ${ }^{[5]}$, 整理和分析美国各阶段新城新区发展 背景、动因、特征、措施等, 归纳一般特征和规律, 以期对我国新城新区发展 提供借鉴。 
表 1 美国新城新区大事件年表

\begin{tabular}{|c|c|c|c|c|c|c|}
\hline 时间 & 名称 & 地点 & 主导者 & 特点 & 面积 $\left(\mathbf{k m}^{2}\right)$ & 相关背景 \\
\hline 1857 & $\begin{array}{l}\text { 新泽西州卢埃林公园（Llewellyn } \\
\text { Park, NJ） }\end{array}$ & 距纽约 $19 \mathrm{~km}$ & 开发商 & $\begin{array}{l}\text { 郊区住宅房地产社区,最早的规划社区（planned } \\
\text { suburbs）之一, 离城市近且有乡间美景 }\end{array}$ & 1.71 & \multirow{3}{*}{$\begin{array}{l}\text { 同时期英国企业城镇发 } \\
\text { 展, 如 } 1851 \text { 年索尔特 } \\
\text { 建设的索尔泰尔工人镇 } \\
\text { (Saltaire), } 1887 \text { 年 利 } \\
\text { 威尔建设的阳光港工人 } \\
\text { 镇 (Port Sunlight) }\end{array}$} \\
\hline 1868 & 伊利诺伊州河岸（Riverside, IL） & 距芝加哥 17.7 km & 开发商 & 郊区住宅房地产社区 & 6.5 & \\
\hline 1880 & 伊利诺伊州普曼（Pullman, IL） & 距芝加哥 21 km & 开发商 & 普曼豪华车厢公司工厂建的工人出租房社区 & 16 & \\
\hline 1906 & 印第安纳州盖瑞（Gary, IN） & 距芝加哥 40 km & 开发商 & 盖瑞钢铁厂逐步发展为城市 & $\underline{148.1}$ & \multirow{5}{*}{$\begin{array}{l}1898 \text { 年霍华德田园城市 } \\
\text { 的提出以及 } 1903 \text { 年英 } \\
\text { 国第一个田园城市莱奇 } \\
\text { 沃斯 (Letchworth) 的 } \\
\text { 诞生, 对美国 } 20 \text { 世纪 } \\
\text { 初郊区社区发展产生显 } \\
\text { 著影响 }\end{array}$} \\
\hline 1911 & $\begin{array}{l}\text { 纽约市森林小丘花园（Forest Hills } \\
\text { Garden, NY） }\end{array}$ & 纽约市皇后区 & $\begin{array}{c}\text { 公益组织、 } \\
\text { 开发商 }\end{array}$ & $\begin{array}{l}\text { 住宅社区, 田园城市理念, 都铎风格, 面向中 } \\
\text { 收人工人家庭 }\end{array}$ & 0.57 (初始) & \\
\hline 1922 & $\begin{array}{l}\text { 密苏里州乡村俱乐部购物中心 } \\
\text { (Country Club Plaza, MO) }\end{array}$ & 距堪萨斯市 6.44 km & 开发商 & 第一个汽车导向的购物中心 & 0.223 & \\
\hline $\begin{array}{c}1924- \\
1928\end{array}$ & $\begin{array}{l}\text { 纽约森尼赛德公园 (Sunnyside } \\
\text { Gardens, NY) }\end{array}$ & 纽约市皇后区 & $\begin{array}{l}\text { 建筑师、 } \\
\text { 规划师 }\end{array}$ & $\begin{array}{l}1923 \text { 年美国区域规划协会 (RPAA) 成立, 由 } \\
\text { 其成员主导设计和投资, 田园城市理念的实践 }\end{array}$ & 0.31 & \\
\hline 1929 & 纽约雷德朋（Radburn, NJ） & 距纽约市 $30 \mathrm{~km}$ & $\begin{array}{l}\text { 建筑师、 } \\
\text { 规划师 }\end{array}$ & $\begin{array}{l}\text { 美国区域规划协会（RPAA）主导设计和建设, } \\
\text { 田园城市理念、邻里单元理念的实践, 人车分流、 } \\
\text { 公共绿地空间 }\end{array}$ & 0.6 & \\
\hline 1935 & 绿带城镇 & & 联邦政府 & & & \multirow{4}{*}{$\begin{array}{l}1933 \text { 年经济危机一大 } \\
\text { 萧条 (Great Depression) } \\
\text { 和罗斯福新政 }\end{array}$} \\
\hline 1935 & 马里兰州绿带 (Greenbelt, MD) & 华盛顿特区附近 & 联邦政府 & \multirow{3}{*}{$\begin{array}{l}\text { 大萧条后罗斯福新政的举措之一, 由重新安置 } \\
\text { 局 (United States Resettlement Administration) } \\
\text { 主导, 目标为中低收人人群, 乌托邦理念下自 } \\
\text { 给自足社区建设, 刺激经济发展和就业。 }\end{array}$} & 16.42 & \\
\hline 1935 & 威斯康星州绿谷（Greendale, WI） & 密尔沃基附近 & 联邦政府 & & 14.43 & \\
\hline 1935 & 俄亥俄州绿山（Greenhills, OH） & 辛辛那提附近 & 联邦政府 & & 3.24 & \\
\hline 1947 & 纽约莱维敦（Levittown, NY) & 距纽约市 50 km & 开发商 & 中产住宅区, FHA 贷款政策支持下, 战后郊区化 & 17.8 & \multirow{6}{*}{$\begin{array}{l}1945 \text { 年二战结束, 美国 } \\
\text { 经济腾飞, 新区发展多 } \\
\text { 样化 }\end{array}$} \\
\hline 1951 & $\begin{array}{l}\text { 斯坦福工业园区（Stanford Industry } \\
\text { Park） }\end{array}$ & 距离斯坦福大学 3.2 km & 大学 & $\begin{array}{l}\text { 第一个科技园, 大学科研向企业研发的转化, } \\
\text { 成就了今天的硅谷 }\end{array}$ & 2.83 & \\
\hline 1954 & 亚利桑那州扬镇（Youngtown, AZ） & 距凤凰城 $25 \mathrm{~km}$ & 开发商 & 第一个退休住宅社区 & 1.3 & \\
\hline 1954 & $\begin{array}{l}\text { 密歇根州北地购物中心（Northland } \\
\text { Center, MI） }\end{array}$ & 距底特律约 90 km & 开发商 & 当时最大的购物中心 & 0.13 & \\
\hline 1956 & $\begin{array}{c}\text { 明尼苏达州南谷购物中心 } \\
\text { (Southdale Center, MN) }\end{array}$ & \begin{tabular}{|l|} 
近双城, 距明尼阿波利斯 \\
$15 \mathrm{~km}$, 距圣保罗 $30 \mathrm{~km}$
\end{tabular} & 开发商 & 第一个完全内化的购物中心 & 0.12 & \\
\hline 1959 & $\begin{array}{l}\text { 北卡罗来纳州三角研究园（Research } \\
\text { Triangle Park, NC） }\end{array}$ & $\begin{array}{l}\text { 三城中心 : 罗利 (Raleigh)、 } \\
\text { 达勒姆 (Durham) 和教 } \\
\text { 堂山 (Chapel Hill) }\end{array}$ & $\begin{array}{l}\text { 州政府和 } \\
\text { 地方政府 }\end{array}$ & 高科技研发园, 靠近三个城市三个大学 & 28 & \\
\hline 1960 & 亚利桑那州太阳城（Sun City, AZ） & 距风凰城 $25 \mathrm{~km}$ & 开发商 & $\begin{array}{l}\text { 老龄城, 社区、购物中心、娱乐中心、高尔夫 } \\
\text { 球场等, 逐年扩大规模 }\end{array}$ & $\underline{38}$ & $\begin{array}{l}\text { 1966-1974 年“伟大社 } \\
\text { 会”下的示范城市项目 }\end{array}$ \\
\hline 1964 & 弗吉尼亚州雷斯顿（Reston, VA） & $\begin{array}{l}\text { 距华盛顿杜勒斯国际机场 } \\
\text { (IAD) } 10 \mathrm{~km}\end{array}$ & 开发商 & $\begin{array}{l}\text { 二战后第一个采用联排住宅（townhouse）形式 } \\
\text { 的社区, 高密度和较大开敞空间, 在华盛顿特 } \\
\text { 区郊区, 近机场; 后来成为 “新城市主义” }\end{array}$ & 27 & $\begin{array}{l}1967 \text { 年英国二战后新城 } \\
\text { 米尔顿・凯恩斯（Milton } \\
\text { Keynes）建成; } 1970 \text { 年美 } \\
\text { 国郊区人口超过城市中心 }\end{array}$ \\
\hline 1967 & 马里兰州哥伦比亚 (Columbia, MD) & $\begin{array}{l}\text { 距巴尔的摩华盛顿国际机 } \\
\text { 场（BWI） } 10 \mathrm{~km} \text {, 位于华 } \\
\text { 盛顿和巴尔的摩之间 }\end{array}$ & 开发商 & $\begin{array}{l}\text { 与雷斯顿 (Reston) 类似的新城 ; 规模更大更 } \\
\text { 综合, 居住 + 就业 + 娱乐 ; 提供多种住宅选择, } \\
\text { 就业机会, 混合利用 ; 后来成为 “边缘城市” }\end{array}$ & 83.4 & $\begin{array}{l}1967 \text { 年美国新城建设需 } \\
\text { 要社会学家的参与 }\end{array}$ \\
\hline 1981 & 佛罗里达州锡赛德（Seaside, FL） & $\begin{array}{l}\text { 位于巴拿马城海滩 } \\
\text { (Panama City Beach) 与 } \\
\text { 德斯廷 (Destin) 之间 }\end{array}$ & $\begin{array}{l}\text { 规划师、 } \\
\text { 开发商 }\end{array}$ & $\begin{array}{l}\text { 新城市主义第一作,传统街区发展模式 (TND) } \\
\text { 和交通导向的发展模式 (TOD) 理念, 回归传 } \\
\text { 统邻里 }\end{array}$ & 0.32 & \multirow{2}{*}{$\begin{array}{l}1973 \text { 年俄勒冈州土地利 } \\
\text { 用立法, 确定了城市增 } \\
\text { 长边界 (UGB) 理念, } \\
1990 \text { 年代开始, 新城市 } \\
\text { 主义广泛传播 }\end{array}$} \\
\hline 1996 & 佛罗里达州庆典镇（Celebration, FL） & \begin{tabular}{|l} 
位于华特迪士尼世界度假 \\
区旁边
\end{tabular} & 开发商 & $\begin{array}{l}\text { 迪士尼公司建的新城；1966 年华特 - 迪士尼就提 } \\
\text { 出了明日社区试验原型的宏伟构想（Experimental } \\
\text { Prototype Community of Tomorrow), 但未成功 }\end{array}$ & 20 & \\
\hline
\end{tabular}

注: 下划线数据为人口普查区 (census) 数据, 可能偏大。

资料来源：该表根据斯科特 - 坎贝尔教授（Scott Campbell）总结的规划史时间线中有关新城新区的重大事件及相关资料和数据整理而成。参见 http://www-personal.umich.edu/ sdcamp/ up540/timeline $12 . h t m l$ 


\section{9 世纪后半叶 : 大城市近郊的田园社区的兴起}

美国内战结束后, 随着工业化和城市化进程加快, 大量 农村人口转移到城市, 不少城市问题也随之出现, 例如交通 拥堵、环境污染、住房紧缺、犯罪率高等 ${ }^{[6]}$ 。然而此时, 现 代意义上的城市规划尚未出现。城市生活环境的逐步恶化引 发了人们对于乡村安静优美田园生活的向往, 形成了自发的 分散发展的现象。这一时期, 一些开发商看到了城市郊区兴 建住宅区的商机, 进行了成功的郊区新社区开发活动, 可以 说是美国工业化之后最早的“新城” 或 “新区” 开发实践。 例如位于新泽西州的卢埃林花园, 建于 1857 年, 是美国最 早的经规划的社区之一, 距离纽约市 $19 \mathrm{~km}$, 占地 $1.7 \mathrm{~km}^{2}$, 吸引了不少名人居住 ${ }^{[7]}$; 再如伊利诺伊州的河岸社区, 建于 1868 年, 距离到芝加哥市中心 $17.7 \mathrm{~km}$, 选址在沿德斯普兰 斯河 (Des Plaines River) 的 $6.5 \mathrm{~km}^{2}$ 的林地上, 结合地形, 设计了为居民提供绿地、开敞空间的公园系统 ${ }^{[8]}$ 。2014 年人 口达到 8881 人 $^{[9]}$ 。

这些郊区居住社区的特征可归纳如下：(1) 建设目的 是跳出大城市, 逃离拥堵、污染、嘈杂的环境, 寻求优美宜 人恬静的乡村生活空间；(2) 在区位上与大城市保持较近的 距离, 在追求田园生活的同时, 享受城市带来的种种便利;

（3）社区开发为纯市场行为; (4) 注重规划, 开发商聘请 规划师、建筑师、景观设计师等, 前期开展充分的选址工作, 并进行整体社区、建筑和景观设计, 创造宜居的景观, 营造 乡村感; (5) 面向富裕的中产阶级。这一时期郊区新社区的 实践, 在取得了商业成功的同时, 丰富了城市规划的内容, 为日后美国化的 “田园城市” 理论总结提供了实践素材。

\section{9 和 20 世纪之交 : 企业城镇的出现}

工业化过程中, 一些大型企业主动承担起为职工提供 住房的责任, 建造城镇, 提供基本服务。更早的实践出现 在英国, 例如 1851 年泰特斯 - 索尔特爵士 (Sir Titus Salt) 建设的索尔泰尔工人镇 (Saltaire)、1888 年威廉 - 赫斯基思 - 利弗 (William Hesketh Lever) 建设的阳光港工人镇（Port Sunlight) 等。在美国, 两个经典案例分别是 1880 年的伊 利诺伊州的普曼镇 (Pullman) 和 1906 年的印第安纳州盖瑞 市 (Gary)。前者是普曼豪华车厢公司（Pullman's Palace Car Company) 为其工人所建的新型工人社区, 位于芝加哥南 $21 \mathrm{~km}$, 占地 $16 \mathrm{~km}^{2}$, 但其中只有 $15 \%$ 用来盖工厂, 其余为 工人居住和其他配套设施 ${ }^{[10]}$ 。普曼力图打造一个良好社区范 本, 这是美国第一个企业城镇 (company town)。后者是美 国钢铁公司 (United States Steel Corporation) 为其新工厂而 建的企业城, 位于密歇根湖南端, 既靠近芝加哥, 可连通五
大湖方便运输, 又有铁路可运输来自明尼苏达的矿石以及东 部和南部的煤。1909 年, 盖瑞正式设市, 人口达到 16000 人, 到 1920 年人口达到 55000 人, 1960 年人口达到高峰, 为 178320 人 $^{[11]}$ 。

纵观这些企业城的产生与发展, 值得注意的有两点: (1) 企业城镇的产生都是企业主动行为。企业为解决职工 生活问题, 不仅关注生产, 而且关注职工生活, 为其建设住 宅; (2) 企业城镇的发展, 直接与企业（产业）的兴衰挂钩, 折射出企业办社会存在的可持续性的问题。例如印第安纳州 的盖瑞市在钢铁产业发展最好的时候, 曾为 25000 人提供 就业, 1960 年盖瑞市有近 18 万人口, 但随着产业结构的调整、 公司的倒闭, 到 2010 年仅剩约 8 万人口。目前盖瑞市饱受 “鬼 城”（Ghost Town）困扰，2013 年 NBC 新闻报道该城 7000 处房地产中有 6500 处被遗弃, 城市政府由于没钱拆除, 考 虑以每栋 1 美元进行拍卖 ${ }^{[12]}$ 。

\section{0 世纪早期 : 田园城市影响下的新城新区开发}

“田园城市” 的理念是由霍华德于 1898 年在其著作《明 日, 一条通向真正改革的和平道路》(To-morrow: A Peaceful Path to Real Reform) 中提出, 目标是建设一个经过规划的, 自给自足的, 绿带包围的, 包含居住、工业和农业的社区 ${ }^{[13]}$ 。在 “田园城市运动” (Garden City Movement) 的推动下, 英国于 1903 年建了第一个田园城市莱奇沃斯（Letchworth）。 随后, 田园城市的理念和方法产生了世界范围的深远影响。

田园城市尚未提出的 19 世纪后半叶, 美国已经有了类 似的实践; 而在田园城市理念提出之后, 美国更多的新建社 区开展了类似的实践, 进一步强化了美国本来就已经出现的 居住区郊区化和园区化的倾向, 强调将规划师、建筑师、景 观设计师集合在一起开展方案设计, 为美国开展较高密度的 居住区开发和向中低收人者提供更健康的居住生活场所提供 了重要支撑 ${ }^{[14]}$ 。例如纽约市皇后区的森林小丘花园 (Forest Hills Garden）根据英国田园城市理念设计, 并采取了都铎式 房屋设计风格 (Tudor-style homes), 强调采光、通风、休憩 场所、绿地空间等方面, 还立足于为中等收人工人阶级家庭 提供住宅 ${ }^{[15]}$ 。

这一时期值得关注的一个重要变化是, 新社区的开发 建设不仅是市场主导的行为, 美国的规划师、建筑师、景 观设计师等开始发挥重要的作用。尤其是 1923 年成立的 美国区域规划协会（RPAA: Regional Planning Association of America), 大力宣扬田园城市的理念, 对美国之后的郊区化 发展起到了重要推动作用。该协会由建筑师、规划师、社 会学家等组成, 协会倡导者为克拉伦斯 - 斯坦 (Clarence Stein), 核心成员还包括本顿 - 麦凯 (Benton MacKaye)、刘 
易斯・芒福德（Lewis Mumford）、亚历山大・宾（Alexander Bing) 和亨利・赖特 (Henry Wright) 等。面对工业城市的 种种弊病, 美国区域规划协会提倡通过合理规划, 分散创造 新城, 将效率、美和社会平等结合起来, 城市融人区域的绿 色景观之中, 回归自然 ${ }^{[16]}$ 。

更为值得关注的是, 该协会成员不仅在理念上推崇田园 城市, 还亲自动手开展了一系列实践。在此之前的实践都是 开发商聘用规划师、建筑师等来做规划; 而美国区域规划协 会的规划师和建筑师则联合开发商一起, 将理念转化为现实, 创造了若干经典范例。例如 1924-1928 年建设的纽约市的阳 光花园 (Sunnyside Gardens), 由该协会核心成员克拉伦斯 · 斯坦、亨利・赖特和开发商亚历山大·宾组建的开发公司 (City Housing Corporation）设计建设, 通过在建筑前后布局花园 打造田园感, 为低收人者提供独户、双户、三户和公寓住宅, 通过增加开敞空间（建筑仅占 $28 \%$ 的土地）实现乡村与城市 生活的融合 ${ }^{[17]}$ 。再如, 这家公司于 1929 年开发建设了新泽 西州的雷德朋 (Radburn, New Jersey), 除了多样化的住宅选 择之外, 还引人了 “大街区” (Super-block) 的概念, 采取尽 端路式的组团, 并创造性地提出了人车分流的交通设计理念, 成为美国今后一个时期居住区设计的典范 ${ }^{[18]}$ 。

\section{0 年代 : 联邦政府首次参与新城建设}

美国联邦政府第一次参与新社区建设是在 20 世纪 30 年 代, 作为应对 “大萧条” 的罗斯福新政 (The Roosevelt New Deal) 的措施之一。罗斯福新政所采取措施主要是刺激经济 增长和增加就业, 缓解经济危机和社会矛盾, 以及兴建公共 设施和基础设施工程, 新社区建设恰逢其时。联邦政府成 立了重新安置局, 并由联邦政府出资实施了 “绿带城镇” (Greenbelt Towns) 项目。

绿带城镇项目的目标是为低收人者提供可支付住房与 就业机会。项目倡导人雷克斯福德 - 特格韦尔 (Rexford Tugwell) 希望, 通过社区建设和环境塑造帮助社区凝聚精神 并促进居民间的合作, 为美国城镇规划建设提供典范 ${ }^{[19]}$ 。其 规划设计贯彻了田园城市的理念, 试图证明一种新的郊区 生活模式 ${ }^{[20]}$ 。联邦政府一共完成了三个绿带城镇示范项目, 分别是马里兰州绿带 (Greenbelt, Maryland)、威斯康星州 绿谷 (Greendale, Wisconsin)、俄亥俄州的绿山（Greenhills, Ohio)。其共同特征包括 : (1) 靠近大城市, 从而确保居民 的就业机会, 其中绿带位于华盛顿特区北 $19 \mathrm{~km}$, 绿谷位于 密尔沃基市西南方向 $19 \mathrm{~km}$, 绿山位于辛辛那提北 $30 \mathrm{~km}$;

（2）每个城镇都设有社区商业中心、社区学校和活动中心、 政府办公室, 住宅分布在这些中心周围, 周边布局广阔绿地;

（3）社区为低收人家庭提供可支付住房；（4）住宅到社区
中心之间通过步道连接, 交通设计考虑安全因素 ${ }^{[21]}$

然而, 联邦政府的绿带城镇项目完成了且仅完成了这三 处, 后续逐渐出现政府运营的弊病。1949-1954 年, 联邦政 府被迫将绿带城镇出售给了个人或私营公司, 仅收回 3600 万美元投资的 $53 \%$ 。三个城镇中, 也仅有靠近华盛顿特区的 绿带一直发展良好, 人口持续增长, 从 1940 年的 2831 人增 长到 2010 年的 23068 人; 相比之下, 其他两个绿带城镇项目 则从 60 年代 “婴儿潮” (Baby boom) 后一直存在人口减少的 问题 (表 2) ${ }^{[22]}$ 。因此, 从推广范围来看, 绿带城镇项目很 难说是成功的。

\section{5 二战后 : 郊区批量式生产的居住社区}

20 世纪五六十年代, 美国经济发展迅速, 住房需求增加, 富裕的中产阶级从城市迁往郊区居住, 出现了专门化、标准 化、规模化的住宅生产, 在城市郊区形成了大量新社区。这 主要与几个因素有关: (1) 伴随经济增长和人们收人的提高, 富裕中产的住宅需求随之提高；(2) 二战后美国迎来 “贞儿 潮”, 1946-1964 年的 18 年间贞儿潮人口高达 7600 万人, 新增人口导致住房需求激增 ${ }^{[6]}$; (3) 联邦政府实施的抵押贷 款政策激励; (4) 州际高速公路的建设, 改善了交通环境, 使得居住在郊区、工作在城市成为可能; (5) 白人外迁（white flight), 尤其是富裕白人中产阶级迁往郊区居住, 形成了一 些种族较为单一的郊区或远郊区住宅区。

这一时期批量式生产居住社区的典型案例是位于纽约市 东南长岛的莱维敦。这是为满足二战后普通市民和退伍军人 住房需求而开发建设的新城。每栋住宅体量小、造价低、结 构简单, 配备有家具和厨卫设施。为了加快建设进度, 降低 建设成本, 开发商将住宅建造流程化, 推动了房屋建造业工 业化。运用预先制造的房屋半成品, 工人最快能够在 16 分 钟内将半成品组装成房屋。一套独立住宅售价仅为 7990 美 元, 对当时美国家庭（平均年收人 5000 美元）来说具有很 大的吸引力。到 1951 年, 莱维敦已经超过 17000 套住宅, 容纳将近 10 万人居住 ${ }^{[6]}$ 。莱维敦取得了巨大的商业成功, 也成为战后美国郊区化的一个象征, 但因其单调、重复、缺 乏特征的规划设计风格、不同用途土地利用的割裂和缺乏联 系, 以及其存在的种族隔离问题, 受到广泛的批判。

\section{表 2 三个绿带城镇的人口规模变化}

\begin{tabular}{ccccccccc}
\hline 时间 & $\mathbf{1 9 4 0}$ & $\mathbf{1 9 5 0}$ & $\mathbf{1 9 6 0}$ & $\mathbf{1 9 7 0}$ & $\mathbf{1 9 8 0}$ & $\mathbf{1 9 9 0}$ & $\mathbf{2 0 0 0}$ & $\mathbf{2 0 1 0}$ \\
\hline Greenbelt, MD & 2831 & 7074 & 7479 & 18199 & 17332 & 21096 & 21456 & 23068 \\
Greendale, WI & 2527 & 2752 & 6845 & 15089 & 16928 & 15128 & 14405 & 14046 \\
Greenhills, OH & 2677 & 3005 & 5407 & 6092 & 4927 & 4393 & 4103 & 3615 \\
\hline
\end{tabular}

资料来源 : US census 


\section{0 年代 : 美国新城发展的三个新形式}

在 20 世纪中期, 美国的郊区社区发展和建设出现了不 同的类型, 体现出专业化和特色化的特征。除纯粹的居住社 区或具有部分商服功能的居住社区外, 还出现了依托城郊购 物中心发展的新城、依托大学建设的高科技产业城和为退休 人群建设的老龄城。

\section{（1）依托城郊购物中心发展的新城}

早在 1922 年密苏里州就出现了美国第一个小汽车导向 的郊区购物中心一专村俱乐部购物中心（Country Club Plaza)。这个购物中心距离堪萨斯城约 $6 \mathrm{~km}$, 采用西班牙式 建筑设计风格, 建设成露天开放式的商店街, 15 个街区共有 150 多个商店和众多餐馆, 吸引人们驱车前往购物 ${ }^{[23]}$ 。2 20 世 纪五六十年代, 这样的郊区购物中心在美国得到普及, 例如 1954 年密歇根州的北地购物中心 (Northland Center, MI), 位于底特律都市区范围内, 占地 $0.64 \mathrm{~km}^{2}$, 零售业建筑面积 9 万多 $\mathrm{m}^{2}$, 是当时美国最大的购物中心, 开业不久每天都吸 引 4 万 5 万人前往 ${ }^{[24]}$ 。

大型郊区购物中心吸引顾客的同时也带动了当地的经济 发展, 围绕着购物中心逐渐发育形成小城镇。典型的案例之一 是位于华盛顿特区西侧首都高速环路（Capital Beltway 495）旁 的泰森角购物中心（Tysons Corner Center）。其发展历程代表 了典型 “边缘城市” (edge city) 的发育过程。该购物中心于 1962 年批准建设, 在一块 $0.61 \mathrm{~km}^{2}$ 的三角形地块内建设了当 时世界上最大的室内购物中心。因其区位优势和交通便利, 周边陆续吸引了公司企业在此集聚, 经过了 40 多年的发展, 泰森角地区从宁静的乡村地区发展为美国第 12 大的 CBD, 为 10 万余人提供就业, 并有约 17000 居民在此居住 ${ }^{[25]}$ 。

(2) 依托大学建设的高科技产业城

世界上第一个大学科技园诞生于美国。1951 年建立的斯 坦福产业园可以看作美国新城发展的另一种新类型。该产业 园距离斯坦福大学约 $3 \mathrm{~km}$, 旨在促进产学研的结合。学校对 人园企业提出了严格要求, 并通过严格审批确保吸引高新技 术产业, 促进学校与企业的合作。产业园最初只有 $0.85 \mathrm{~km}^{2}$, 之后由于发展良好而不断扩大, 1960 年园区扩展到 $1.82 \mathrm{~km}^{2}$, 有超过 40 家企业; 1980 年扩展到 $2.43 \mathrm{~km}^{2}$, 有超过 100 家企业; 今天园区面积达 $2.83 \mathrm{~km}^{2}$, 有 150 家公司 ${ }^{[26]}$ 。

另一个成功发展案例是北卡罗来纳州的三角产业园。园 区建于 1959 年, 位于三个较大城市之间的黄金区位, 三个 城市各有一所知名大学, 即杜克大学 (Duke University), 北 卡州立大学 (UC State University) 和北卡大学教堂山分校 (University of North Carolina at Chapel Hill)。目前产业园占 地 $28.3 \mathrm{~km}^{2}$, 有超过 200 家公司, 提供 5 万人就业 ${ }^{[27]}$ 。三角
产业园的成功包括：一是时机, 产业园成立的时候恰逢政府 和商业领袖都认识到了科学技术和研究对于企业和经济发展 的重要性; 二是与大学的合作, 产业园周边三所大学和其他 研究机构为产业园提供了充分的智力支持; 三是规模, 产业 园所在区域为产业园提供了各类专业化劳动力资源, 促进了 集聚经济和技术溢出; 四是坚持, 产业园的倡导者从一开始 就认识到了园区发展需要 10 年、20 年的较长发展之后才能 得到回报，地方官员和居民也就为实现共同长远目标达成共 识和不解努力。

值得注意的是, 不论是斯坦福产业园还是三角产业园都 是由市场发起的。斯坦福产业园为大学主导发展, 三角产业 园则由私人努力和大学参与, 而不是政府资助的项目。虽然 不能否认地方政府对于产业园的发展给予了大量支持，但应 当承认市场主导的发展模式是美国高科技产业园成功的重要 因素。

(3) 老龄城

20 世纪 50 年代美国还出现了针对退休人群的老龄城。 1954 年, 亚利桑那州扬镇中 2 个开发商买了 $1.3 \mathrm{~km}^{2}$ 的土地, 建设了美国第一个退休社区。当今, 扬镇在 $5 \mathrm{~km}^{2}$ 范围内有 6200 个居民, 7 个公园, 1 个湖, 3 个商业中心, 为居民提 供步行范围内的服务 ${ }^{[28]}$ 。扬镇旁的太阳城（建于 1960 年） 作为更大规模的退休社区, 成为世界知名的退休社区典范。 公司最初计划在 3 年内卖掉 1700 栋房屋, 结果第一年就卖 了 2000 栋 $^{[29]}$ 。社区逐步完善了购物、医疗、护理、休闲、 宗教等设施, 目前 $38 \mathrm{~km}^{2}$ 内有 38000 人, 其中 $80 \%$ 的人口 为 65 岁以上。德尔.韦伯开发公司 (Del Webb Development Company）在美国开发了 20 多个以太阳城命名的老年社区, 亚利桑那州、加利福尼亚州和弗罗里达州的太阳城面积都达 到 $20 \mathrm{~km}^{2}$ 以上。

上述三种新城的成功发展, 事实上折射出三种创新的理 念：（1）郊区购物中心充分利用了高速路的通达性和郊区低 廉的地价；（2）高科技产业城充分结合商业的资本优势和大 学的科研优势; (3) 退休社区为老年人提供了前所未有的生 活环境和方式。值得注意的是, 这三种新社区均为市场挖掘 出的新增长点。在市场经济发达的背景下, 政府对于新社区 开发并未投人过多的关注, 而是主要依靠市场就产生了较高 的投资回报并实现了高效率的城镇发展。此外，这三种新社 区的兴起也反映了专业化和特色化的发展优势。

\section{0 年代和 1970 年代 : 私人开发的综合新城 的成功和政府造城运动的失败}

20 世纪 60 年代和 70 年代, 美国无论是市场还是政府 都对新城发展非常重视。一方面, 有抱负的开发商越来越不 
仅满足于单纯的住宅区开发, 而是尝试建设更为综合化的城 镇, 除了经济利润, 开发商也开始关注城市问题、环境问题 和社会问题，尝试打造宜居、开放、平等、高效的理想城镇; 另一方面, 联邦政府第二次插手新城建设, 在全社会对社会 贫困问题、住房问题和民权问题等倍加关注的背景下，作为 约翰逊总统 “伟大社会” (Great Society) 计划的一部分, 实 施了联邦政府资助的新城镇开发建设。然而, 从结果来看, 这两方在新城发展建设方面的努力却是截然不同的。

比较而言，市场一方的实践更为成功。典型案例是位 于华盛顿特区大都市区范围内的弗吉尼亚州的雷斯顿。雷 斯顿由纽约开发商罗伯特 - 西蒙（Robert E. Simon Jr.）于 1961 年购买土地和主导规划建设, 这一地区距离杜勒斯国 际机场（IAD）仅 $10 \mathrm{~km}$ ，交通便捷，2010 年该地区人口 $58404^{[22]}$, 已经发展成为一个典型的 “边缘城市”。雷斯顿 在美国规划史上具有重要的地位，除因其发展十分成功、商 业利润可观之外，其在规划设计和规划管理方面的贡献更值 得关注。(1) 在规划编制方面, 西蒙邀请规划师、建筑师、 经济学家、社会学家、心理学家和娱乐、宗教界人士共同 出谋划策 ${ }^{[6]}$, 确保规划的合理性。(2) 在公众参与方面, 公 众参与过程贯穿于规划、建设和建成后管理的各阶段, 包 括开发商搭建跨学科交流平台、设立管治机构、成立市民 组织等 ${ }^{[6]}$ 。(3) 在规划法律支撑方面, 西蒙成功劝说菲尔菲 克斯县当局（Fairfax County Board of Supervisors）通过了一 项法令 (ordinance), 允许高密度住宅建设 (closer clustering of housing）。（4）在空间组织方面, 通过较高密度的组团式 开发, 将更多空间用于集中的绿地等开敞空间，从而提高 社区的景观风貌和环境质量, 形成乡村环境下的城市景观。

（5）在就业功能方面, 将 $4 \mathrm{~km}^{2}$ 用作产业用地, 为当地居 民提供就业。(6) 在运营管理方面，与新社区所在县政府共 同努力建立了一个行政管理机构，设立了特别税区 (special tax district)，对财政予以支持。

与雷斯顿类似，同样位于华盛顿特区大都市区外围，始 建于同时期但规模更大的另一个 “边缘城市”一 马里兰州 的哥伦比亚, 也是由私人投资主导成功发展的综合城镇。罗 斯也是位很有规划理想的开发商, 定位于建设一个自给自足, 融生活、就业、休闲于一体, 促进自由和种族平等的新城。 2010 年, 哥伦比亚人口有超过 10 万人居住。

归纳这一时期市场主导的的综合性新城发展的成功要 素, 包括：(1) 与早期郊区社区发展成功案例类似, 仍然是 区位, 雷斯顿和哥伦比亚都依托华盛顿特区大都市区而建设 发展, 从而确保充足的需求; (2) 交通条件, 考虑到美国是 个 “车轮上的国家”, 成功的新社区发展必然需要靠近高速 公路作为保障；(3) 广泛参与下的精心规划, 由于目标是打
造具有相当规模的综合性城镇, 规划的内容比以往更加复杂, 广泛的参与和合理的规划过程就十分重要, 事实上, 这一时 期新社区规划制定和规划实施管理的实践与当时学术界提出 的倡导式规划、协作式规划和沟通式规划等理论是相契合的;

(4) 将综合功能作为规划目标并逐步实现, 在两个案例中, 商业与企业以及其提供的就业是新城成功发展必不可少的条 件，确保了社区对居民的吸引力和持续的经济活力。

在这一时期, 联邦政府又一次插手新城计划的失败则与 几个因素有关。(1) 1960 年代未解决通胀和越战困扰, 约 翰逊政府 “伟大社会” 的推子铺得太大, 后来的尼克松政府 对新城建设态度并不十分支持；(2) 政府内部对于新城计划 存在分歧, 例如白宫就持反对意见, 预算局也多次拒绝按照 1970 年法案的规定分配 5 亿美元担保贷款；（3）财政激励 相对开发投资太少, 开发商需要高利率借贷从而获得土地、 雇佣规划师和开展建设, 当销售滞后于预期, 开发商会通过 提高租金来确保利润, 反而排除了相当的潜在购房者, 新城 计划存在财政问题；(4) 时机不好, 上世纪 70 年代美国房 地产市场整体出现下滑; (5) 文化冲突, 美国社会一直以来 推崇市场经济和质疑政府, 此外, 联邦政府主导的新城项目 与上世纪 60 年代开始美国反对自上而下的规划、倡导社区 利益的运动背道而驰。实践似乎表明, 欧洲成功的政府主导 的新城新区发展模式到了美国出现了水土不服。

\section{0 年代 : 新城市主义带来传统的复苏}

美国最近一波的新城镇发展多半都打着“新城市主义” 的印记。针对蔓延式和跨越式发展带来的问题, 如过度依赖 小汽车、空气污染、自然生态空间占用等, 以彼得 - 卡尔索 普 (Peter Calthorpe)、安德列斯 - 杜安尼 (Andrés Duany)、 伊丽莎白 - 普莱特 - 齐贝克 (Elizabeth Plater-Zyberk)、伊丽 莎白 - 莫尔 (Elizabeth Moule) 等为代表的规划师和建筑师 给出的解决方案是 : 复兴传统街区模式, 倡导高密度的紧 凑社区, 采用方格路网取代尽端路, 强调多样化的住房选 择, 提倡混合型土地利用开发, 引人商业服务业, 营造步 行环境, 鼓励绿色交通, 增加社区连片开敞绿色空间等。 其中, 传统街区发展模式 (TND:Traditional Neighborhood Developement) 和公共交通导向的发展模式 (TOD) 是核心 内容, 分别代表了土地利用和交通组织的倡导模式。

新城市主义的倡导者的一大特点是将理念与实践紧密结 合。例如杜安尼和普莱特 - 齐贝克 1980 年创立的公司 (DPZ: Duany Plater-Zyberk \& Company) 在 28 年内设计了美国和其 他国家超过 250 个新城、区域规划、社区重建项目 ${ }^{[30]}$ 。典型 案例包括 1981 年建设的弗罗里达州的锡赛德市和 1988 年建 设的马里兰州的肯特兰镇 (Kentlands, MD) 等。 
新城市主义倡导的新城开发与上世纪早期倡导的郊区新 社区（城镇）发展有所区别。上世纪美国区域规划协会所提 出的实际上是 “区域城市” (regional city) 的概念, 其核心 是为了解决或回避中心城市的问题, 提倡跳出城市发展, 将 新的开发建设融人到更为广阔的区域中, 认为分散能够解决 问题。这种理念在二战后的郊区化过程中实际上推进了过度 的低密度蔓延式发展, 带来了更多的环境和社会问题, 背离 了初衷。新城市主义则是针对这些问题, 回归传统, 认为城 镇发展需要集中, 提倡更为多样化、可步行、紧凑、减少机 动车出行、混合土地利用的社区。

新城市主义也是对当时美国出现的社会问题的回应。 2000 年罗伯特 - 帕特南（Robert Putnam）在其 1995 年文 章的基础上出版了《独自打保龄球：美国社区的衰退与 复兴》(Bowling Alone: The Collapse and Revival of American Community), 观察到美国人越来越少参与社团组织, 反映了 美国社会中人际关系的衰弱, 有损于社会公民积极参与社会 事务, 而这正是民主的前提 ${ }^{[31]}$ 。新城市主义所倡导的创造地 方归属感, 通过规划设计增加社区居民互动, 正是应对人际 关系淡漠、地方社团组织减少、公民精神衰落的问题。

\section{9 美国新城新区发展特点与启示}

从美国新城新区的发展历程来看, 创造出具有乡村优点 的城镇一直是其向往的目标。其基本驱动力来自于工业化、 经济危机、郊区化、小汽车/高速路、后工业时代的人本主 义等。新城新区的形式体现为从郊区化住宅社区、到企业社 区、中产住宅社区、购物中心、科技园、老龄城, 直到综合 城镇。规划理念也不断演变, 呈现更替式、螺旋式的发展 : 先是从跳出城市逃往乡村, 倡导分散、低密度的田园生活, 尽享小汽车带来的便利; 后又回归传统, 从低密度走向高密 度, 从散布趋向集中, 提倡步行和公交等更为绿色的生活方 式, 从以自我发展为重变为以社区为重。因此, 新城新区形 态的演变, 也从模仿乡村如画的形态, 到回归以公共广场为 中心的方格网和公交导向的城市区域网络。

美国新城新区的发展与我国虽然差异较大, 但其发展历 程、经验和教训, 对于我国当前新城新区发展能够有所借鉴, 尤其是在当前我国探索政府与市场协同发展的现阶段。

一是新城新区发展要注重发挥市场的积极作用。美国的 经验表明, 通过市场即可建立成功发展的新城新区, 而不需 要政府过多的投人; 相反, 过度的政府干预可能导致预料之 外的失败后果。政府的支持有必要, 但更应注重发挥市场的 作用, 以弥补政府对投人产出的计算不足, 提高效率, 共担 风险。政府在主导新城发展时尤其要慎重, 必须尊重市场规 律, 防止盲目追求规模, 应加强对公共投资的论证和监管。
二是区位、规模对新城新区发展成功与否有着重要影响。 我国目前部分新城新区位置偏远, 与主城隔离; 规模偏大, 仅基础设施投资就投人巨太。美国的经验表明，成功的新城 新区发展要与主要城市接近, 与机场接近, 与良好环境接近, 区位因素非常关键; 此外, 由于是市场主导, 更多的考虑效 率, 新城新区的规模一般不会一下铺得过大, 而是在充分分 析经济效益的基础上, 根据发展情况逐步扩大规模。此外, 科技园不可能遍地开花, 与大学和资本接近是重要前提, 例 如斯坦福产业园和和三角园就是充分依托了周边大学的智力 要素。

三是将就业作为新城新区发展的核心, 以综合化发展为 方向。不能只看重房地产开发的短期利益, 必须考虑城镇长 远发展。没有就业就没有经济发展, 曾经辉煌的城市也可能 成为鬼城。同时也要警惕产业过于单一的城市的衰落, 例如 曾经的钢铁城市盖瑞市在 1930 年代盛极一时, 但到了 1960 年代损失了 $55 \%$ 的人口。

四是企业和政府应扮演好各自的角色。美国的经验反映 出企业办社会、企业建新城的倾向。事实上, 在需求和利润 的驱动下, 企业投人于城市建设是一种必然。更何况一些企 业也有理念与抱负。政府的作用更多应该是引导和对重要资 源和空间的管控。借鉴新城市主义理念, 政府可通过规划管 理对城市空间进行更优化的配置, 如增加开敞空间和绿地、 营造开放式街区、优化居住和商业的混合利用、倡导公交导 向式发展等。同时充分利用企业参与城市建设和发展, 吸引 社会资金。

五是要有耐心。城市建设发展非一朝一夕, 需要时间 来检验。美国一个成功社区的发展需要几十年。例如华盛顿 特区的哥伦比亚, 从 1967 年开始买地建设, 人口从 1970 年 的 8815 增长到 2010 年的近 10 万人, 今天已经成为美国最 富有的社区之一, 成为 “边缘城市” 的典范。再如政府主导 的绿带, 后来卖给市场运营, 发展至今历经 80 年, 人口从 1960 年的 2831 增加到 2015 年的 24000 左右, 成为一个成 熟的、团结的社区。美国区域规划协会的开发商亚历山大 宾有一句名言 : 如果仅仅基于投资获利的考虑, 新区建设永 远不会成功。这是由于新城新区建设需要对社区和社会建设 长期投人, 而不是短期的土地投资或房地产开发, 这样才会 最终形成由人构成的新城新区社会。

六是美国的经验反映其工业化后期的发展问题和应对措 施，对我国下一个阶段的城镇化有预警作用。美国经历的一 些问题我们正在经历, 如郊区化、小汽车带来的城市扩张、 居住需求膨胀带来的住宅快速建设, 以及由高速公路网、铁 路网、轨道交通的发展带来的“边缘城市” 的出现等。美国 经历的另一些问题我们目前还不是很严重或未得到重视, 如 
过于单一功能的住宅区发展模式。尽管我国城市发展历史上 是单位制的混合利用模式, 生活较为便利, 但目前城市郊区 迅速建设的大规模封闭居住区中, 有些确实只具备单一居住 功能; 再如种族隔离、收人隔离等, 目前尚不突出, 但随着 居住区档次的拉开，保障性住宅的集中建设，旧城低收人居 民的集体搬迁, 社会隔离和贫困人群的聚集很可能会成为我 们今后需要面对的问题; 再如人际关系的淡漠、城市居民老 龄化等问题, 事实上已经迫在眉睫。UPI

\section{参考文献}

[1] Purdom C B. Town Theory and Practice[M]. London: Benn, 1921.

[2] 冯奎. 中国新城新区现状与创新发展重点 [J]. 区域经济评论, 2016(6): $15-25$.

[3] 贾广葆。新城新区开发建设中的问题、对策及思考 [J]. 国土资源, 2016(6): 40-41.

[4] 刘士林, 刘新静, 盛蓉.中国新城新区发展研究 [J]. 江南大学学报 (人 文社会科学版) , 2013(7): 74-81.

[5] Campbell S. Planning History Timeline: A Selected Chronology of Events (with a Focus on the U.S.)[EB/OL]. [2016-12-12]. http://www-personal. umich.edu/ sdcamp/up540/timeline12.html.

[6] 冯奎. 中国新城新区发展报告 [M]. 北京: 中国发展出版社, 2016.

[7] Llewellyn Park. LP Historical Society and Archives[EB/OL]. [2016-12-12]. http://www.llewellynpark.com/.

[8] Cyber T. Riverside Community Website[EB/OL]. [2016-12-12]. http:// www.riverside-illinois.com/.

[9] Onboard, I. Riverside Illinois[EB/OL]. [2016-12-12]. http://www.city-data. $\mathrm{com} /$ city/Riverside-Illinois.html\#b.

[10] Historic Pullman Foundation. The Town of Pullman[EB/OL]. [2016-12-12]. http://www.pullmanil.org/town.htm.

[11] Advameg, I. Gary: History[EB/OL]. [2016-12-12]. http://www.city-data. com/us-cities/The-Midwest/Gary-History.html.

[12] Engel P. Gary, Indiana Is Deteriorating so much that It May Cut off Services to Nearly Half of Its Land[EB/OL]. (2013-06-20)[2016-12-12]. http://www. businessinsider.com/gary-indiana-is-deteriorating-badly-2013-6.

[13] Howard E. Tomorrow: A Peaceful Path to Real Reform[M]. London: S. Sonnenschein, 1898.

[14] Hall P, Tewder-Jones M. Urban and Regional Planning[M]. London: Routledge, 2011.

[15] DoI. Land Use and Site Development[EB/OL]. [2016-12-12]. https://www. nps.gov/nr/publications/bulletins/suburbs/part2.htm.

[16] 彼得・卡尔索普, 威廉 - 富尔顿。区域城市——终结蔓延的规划 [M]. 叶齐茂, 倪晓晖, 译. 北京: 中国建筑工业出版社, 2007.

[17] Borough of Queens. Sunnyside Gardens[EB/OL]. [2016-12-12]. http:// www.nyc.gov/html/lpc/downloads/pdf/sig/info_ssg.pdf.

[18] The Radburn Association. Radburn: A Planned Community[EB/OL]. [2016-12-12]. http://radburn.org/index.php/about.

[19] Thyme. Greenbelt's History[EB/OL]. (2012-12-06)[2016-12-12]. https:// greenbeltmuseum.org/history/.

[20] Wisconsin N. Greendale: A Planned Community in the Great Depression [EB/OL]. (2012-12-06)[2016-12-12] https://livingnewdeal.org/tag/ greenbelt-towns/.

[21] Village of Greenhills. Greenhills Ohio History[EB/OL]. (2014-02-25)[201612-12]. http://www.greenhillsohio.us/index.php/history.

[22] Census Bureau. U.S. Census[EB/OL]. [2016-12-12]. http://www.census.gov/.

[23] Country Club Plaza. One Man's Visin Shapes the City[EB/OL]. [2016-1212]. http://countryclubplaza.com/art-history/.

[24] Eckhart N. Northland Center in Southfield, Michigan[EB/OL]. (2015-03-
22)[2016-12-12]. http://www.deadanddyingretail.com/2015/03/northlandcenter-in-southfield-michigan.html.

[25] Byron B. Transforming Tysons[EB/OL]. (2014-09-16)[2016-12-12]. http:// www.fairfaxcounty.gov/tysons/download/transformingtysonpresentati on_091614.pdf.

[26] Sandelin J. The Story of the Standord Industry Research Park[EB/OL]. (200403-18)[2016-12-12]. http://otl.stanford.edu/documents/JSstanfordpark.pdf.

[27] RTR. 2016 States of the Research Triangle Region[EB/OL]. [2016-12-12]. http://www.researchtriangle.org/.

[28] ToY. Yesterday \& Today[EB/OL]. [2016-12-12]. http://youngtownaz.org/ Index.aspx?NID=944.

[29] RCoSC. The Original Retirement Community[EB/OL]. [2016-12-12]. http://suncityaz.org/.

[30] Duany A. The End of the Suburbs[EB/OL]. [2016-12-12]. http://newurbanism.org/marketplace.html.

[31] Knack S. Robert D. Putnam, Bowling Alone: The Collapse and Revival of American Community[J]. Public Choice, 2000, 108(3): 390-395.

(本文编辑：秦潇雨) 